\title{
Special Problems in Nursery Propagation of Day-neutral Strawberry Cultivars Susceptible to Colletotrichum acutatum
}

\author{
Thomas M. Sjulin ${ }^{1,2}$ \\ Driscoll Strawberry Associates, 404 San Juan Road, Watsonville, CA 95076-5399
}

Additional index words. disease control, Fragaria $\times$ ananassa

\begin{abstract}
Susceptible day-neutral strawberry (Fragaria $\times$ ananassa Duch.) cultivars are readily infected by Colletotrichum acutatum J.H. Simmonds during nursery propagation. The fungus infects strawberry flowers and fruit under warm, moist conditions and spreads rapidly throughout the nursery planting during repeated cycles of infection. Plants transplanted from infected nurseries into fruit-production fields have increased plant mortality and yield loss. This paper reviews practices adopted by California strawberry nurseries that reduce or eliminate sources of fungal inoculum, reduce strawberry plant susceptibility, or reduce pathogen spread in the nursery. California nurseries are currently using a combination of these practices to produce specific pathogen-free planting stock of susceptible day-neutral cultivars.
\end{abstract}

Day-neutral cultivars of the cultivated strawberry are very important in California's commercial strawberry industry. Since the introduction of the first successful day-neutral cultivar Selva in 1983, the cultivated area of day-neutral cultivars has grown rapidly in both the Watsonville/Salinas district and the Santa Maria district along the coast of California, replacing and expanding upon the summer-planted production acreage of shortday cultivars. Plants of these day-neutral cultivars are produced in high-elevation nurseries in northern California and southern Oregon and are transplanted as fresh-dug plants into the fields in late autumn. In the Watsonville/Salinas district, the state's largest commercial production area, the dayneutral cultivars Albion and Diamante now account for nearly $50 \%$ of the surface area or $\approx 2500$ ha (CSC, 2006). In addition, production in the Santa Maria district from fresh-dug plants of these day-neutral cultivars is $\approx 500$ ha (CSC, 2006). The major reason for the increase in production area of day-neutral cultivars is the extension of the flower-initiation period of day-neutral genotypes relative to short-day genotypes. This extension of flower initiation results in greater season production (Bringhurst et al., 1989), reduces peak volumes as a percentage of total fresh shipments, and extends the fresh market season later in the year, each of which contributes to higher overall returns to the producers (Sjulin, 2003).

A more recent application of day-neutral cultivars, using both public and proprietary cultivars, is midsummer planting of coldstored plants along the southern California coast in both the Santa Maria and Oxnard districts. These plants are primarily produced in low-elevation nurseries located in the Central Valley of California. The production in this application is relatively low yielding but is timed to higher-average pricing periods

\footnotetext{
${ }^{1}$ Present address: Seven Maples Farm, 629 Carpenteria Road, Aromas, CA 95004-9718.

${ }^{2}$ To whom correspondence should be addressed; e-mail: tomkaysjulin@sprynet.com.
}

from mid-September through mid-December. The average returns to the producers have been high, and they have been reinvested into rapid growth of the cultivated area since the system's introduction in the early 1990s. The area cultivated in this system now exceeds 2000 ha (CSC, 2006).

Significant amounts of strawberry dayneutral plants are supplied to producers from various nurseries. About 150 million freshdug plants of day-neutral cultivars are needed annually to supply the 3000 total ha in the Watsonville/Salinas and Santa Maria districts, assuming an average plant density of $50,000 \mathrm{plants} / \mathrm{h}$. An additional 130 million plants of cold-stored plants of day-neutral cultivars are needed annually for the 2000 ha planted at a higher average density $(65,000$ plants/ha) in the summer along the southern California coast. Some California strawberry nurseries also produce additional plants for foundation nursery stock and provide coldstored plants to nurseries and producers in other areas of North America and abroad.

Anthracnose crown and fruit rot, incited by Colletotrichum species, is a serious disease of strawberries and many other crops worldwide (Peres et al., 2005). Strawberry nurseries in the western United States that supply the California fruit production industry are particularly concerned with $C$. acutatum J.H. Simmonds, which can be introduced into fruiting fields by infected planting stock (Eastburn and Gubler, 1990). Plants sold either domestically or abroad should be free of detectable levels of infection by pathogens such as $C$. acutatum, and new sensitive diagnostic techniques (Parikka and Lemmetty, 2004) will require even higher levels of disease control in the nursery fields.

The defining characteristic of a day-neutral cultivar is the ability to produce flowers following lengthy cold storage on the mother plant and daughter plants, even under the relatively warm conditions of California's Central Valley (Bringhurst et al., 1989). This flowering response is the principle reason why Colletotrichum-susceptible day-neutral cultivars are much more problematic in the nursery than comparable susceptible short- day cultivars. The presence of readily infected flower and fruit tissue, combined with the warm, wet conditions typical of strawberry nursery production, create an ideal situation for a disastrous infection by Colletotrichum fungi. Measures will be discussed that reduce the likelihood that such an infection will occur. These measures are elimination of potential sources of inoculum of the pathogen, cultural practices that reduce the susceptibility of the host plant to infection, and chemical and biological control agents.

\section{ELIMINATION OF PATHOGEN INOCULUM}

The first step in reducing the likelihood of infection by Colletotrichum spp. is soil disinfestation. Elimination of the pathogen from the soil is essential, as C. acutatum survives in fallow soils, particularly in infected fruit tissue, for up to 9 months (Eastburn and Gubler, 1992; Eastburn and Gubler, 1990; Freeman et al., 2002; Gubler and Eastburn, 1988; Wilson et al., 1992). Conidia survive longer in cool, dry soils and in soils previously sterilized (Eastburn, 1992; Freeman et al., 2002). Soil fumigation with methyl bromide/chloropicrin mixtures is an effective treatment to eradicate overwintering inoculum, and soil sterilization has also been an effective treatment in warm environments (Freeman et al., 2002).

Consideration must also be given to the separation distance between new plantings and previously infested fields as well as separation from other host crops. Soil fumigation treatments or solarization treatments must extend far enough beyond the edge of new plantings to prevent spread of inoculum from previously infested areas (Freeman et al., 2002). Colletotrichum acutatum conidia are spread by water droplets, dispersal is influenced by wind direction, and dispersal is greater in bare soil than in soil covered with organic mulches (Yang et al., 1990).

Colletotrichum acutatum has a wide host range (Freeman et al., 2001; Peres et al., 2005), and nursery plantings must be kept 
isolated from other hosts that may serve as sources of inoculum. Of special concern to the California strawberry nursery industry are reported outbreaks of $C$. acutatum on almonds (Adaskaveg and Hartin, 1997) and highbush blueberry (Yoshida and Tsukiboshi, 2002), both of which are important crops in the Central Valley region. Although isolates from these two crops were assigned to the same genetic group as some strawberry isolates by Sreenivasaprasad and Talhinas (2005), Peres et al. (2005) did not feel that genetic groups were indicative of host specificity. Isolates from strawberry were not pathogenic on most other crops except cultivated anemone (Anemone coronaria L.) [as cited in Freeman et al. (2001)], and there is little evidence to date of naturally occurring cross-infection from other crops except anemone (Denoyes-Rothan et al., 2003; Forster and Adaskaveg, 1999; Freeman et al., 2001; Peres et al., 2005).

Weed plants near strawberry nurseries may serve as inoculum reservoirs (Freeman et al., 2001). Both $C$. acutatum and $C$. fragariae Brooks are reported to survive on several weed species including $C$. acutatum on Conyza sp. and Vicia sp. (Freeman et al., 2001) and C. fragariae on Senna (Cassia) obtusifolia (L.) Irwin \& Barnaby (Howard and Albregts, 1973). Representatives of both Conyza [e.g., Conyza canadensis (L.) Cronq.] and Vicia [e.g., Vicia sativa L. ssp. nigra (L.) Ehrh.] are commonly found in California (UC IPM Online, 2004; USDA, 2004), and $S$. obtusifolia is reported as well (CDFA, 2004).

Planting stock must also be free of pathogen inoculum. Specific pathogen-free tissue cultured plants have been successfully used as planting stock in Louisiana strawberry nurseries when grown in isolation from other nurseries infected with $C$. fragariae (McInnes et al., 1992). However, the relatively high cost of tissue culture for production of specific pathogen-free planting stock limits its use. An alternative approach is to eliminate Colletotrichum spp. from planting stock by hot water therapy (see below).

Hot water therapy has long been used for elimination of pest and disease problems in dormant stock of strawberry, including cyclamen mites (Phytonemus pallidus ssp. fragariae Zimmerman) and endoparasitic nematodes (Goheen and McGrew, 1954; Goheen et al., 1956; Smith and Goldsmith, 1936). More recently, hot water therapy has been applied to commercial nursery stock for control of C. acutatum (see Strand, 1994 for details on immersion temperature and time). Hot water treatments results in nearly complete eradication of $C$. acutatum, and the level of control exceeds that of registered chemical-dip treatments or other alternative therapies (personal observation). Combined with other disease-management practices, hot water treatment is an important tool for production of strawberry plants of Colletotrichum-susceptible cultivars and is commonly applied today in California strawberry nurseries.

\section{CULTURAL PRACTICES THAT REDUCE HOST PLANT SUSCEPTIBILITY}

Several cultural practices can reduce the likelihood of infection by $C$. acutatum. One important practice is frequent removal of blossom clusters as they emerge on both mother and daughter plants. Nursery workers typically remove blossoms clusters by hand while riding in a prone position on specially constructed equipment. Open blossoms and ripening fruit are highly susceptible to infection by $C$. acutatum, and large amounts of inoculum can quickly develop on these infected tissues, leading to secondary infection of crown tissue.

Another important cultural practice is to reduce standing water in the nursery fields. Overhead sprinkler irrigation is a standard practice in California strawberry nurseries, and disease outbreaks often occur first among plants in low, poorly drained areas of the field or around leaking sprinkler risers. A common practice in California nurseries is to grow susceptible day-neutral varieties on raised beds to improve drainage. Many nursery fields are also irrigated with leak-proof sprinkler pipes that have control valves at each nozzle to prevent leakage of water from sprinkler risers after irrigation sets.

Fertilizers can also affect the susceptibility of strawberry plants to Colletotrichum spp. Smith (1987) found that strawberry plants were more susceptible to $C$. fragariae when ammonium forms of nitrogen were used. A subsequent study found that some forms of calcium fertilizers reduced the incidence of $C$. acutatum fruit infection in greenhouse-grown strawberries (Smith and Gupton, 1993). Limiting nitrogen applications late in the growing season is a recommended strategy to reduce susceptibility of host tissue (Smith, 1998), and most California strawberry nurseries follow this practice; however, this may lead to latent infections (Horowitz et al., 2006).

\section{CHEMICAL AND BIOLOGICAL CONTROL MEASURES}

Until recently, no effective chemical control measures have been available for use in U.S. strawberry nurseries. Strobilurin fungicides (pyraclostrobin and azoxystrobin) are now available, as is an additional product that is a combination of strobilurin and carboxyanilide chemistry (active ingredients are pyraclostrobin and boscalid). Yet another product, a combination of anilinopyrimidine and phenylpyrrole chemistries (active ingredients are cyprodinil and fludioxonil), is registered for control of Botrytis cinerea Pers. ex. Fr. on strawberries, but it also shows activity against Colletotrichum spp. The effectiveness of these products for control of Colletotrichum spp. outbreaks in strawberry nurseries is not yet known, but the postinfection activity of pyraclostrobin appears to be much better than the standard captan fungicide (Turechek et al., 2006). All of these new products must be used carefully and in rotation with different chemistries to avoid development of resistant strains.

The prospects for biological control of $C$. acutatum have also improved recently. Freeman et al., (2004) reported that some Trichoderma isolates were quite effective in reducing plant mortality incited by $C$. acutatum in large-scale experiments. One of these isolates was a commercially available isolate, and the others were isolated from Israeli strawberry fields. PCR technology was also applied to monitor the survival of individual isolates following applications of multiple Trichoderma strains, a technique that should accelerate development of effective combinations of biocontrol organisms.

\section{FUTURE PROSPECTS}

The long-term strategy for control of C. acutatum in day-neutral strawberries must include development of resistant cultivars. Sources of resistance to Colletotrichum spp. fruit and crown infection (Denoyes-Rothan et al., 1999; Galletta et al., 1993; Smith et al., 1998) have been identified in short-day genotypes, and both public and private breeding programs are using these sources. However, no day-neutral cultivars have been developed to date that combine Colletotrichum resistance with acceptable levels of horticultural traits. Until the release of resistant cultivars, effective control of $C$. acutatum in strawberry nurseries will require an integrated approach that includes elimination of inoculum sources, reduction of host susceptibility, and either chemical or biological control.

\section{Literature Cited}

Adaskaveg, J.E. and R.J. Hartin. 1997. Characterization of Colletotrichum acutatum isolates causing anthracnose of almond and peach in California. Phytopathology 87:979-987.

Bringhurst, R.S., H. Ahmadi, and V. Voth. 1989. Genetic regulation of fruiting, p. 307-314. In: C.J. Wright (ed.). The manipulation of fruiting. Butterworths, London.

California Department of Food \& Agriculture (CDFA), Div. Plant Health \& Pest Prevention Services. 2004. Important notice. <http:// www.cdfa.ca.gov/countyag/postings/files/Calif. Weed_Pest.pdf>.

California Strawberry Commission (CSC). 2006. Strawberry review: 2006 acreage survey. Updated Feb. 2006. CSC, Watsonville, CA.

Denoyes-Rothan, B., G. Guerin, C. Delye, B. Smith, D. Minz, M. Maymon, and S. Freeman. 2003. Genetic diversity and pathogenic variability among isolates of Colletotrichum species from strawberry. Phytopathology 93: 219-228.

Denoyes-Rothan, B., M. Lafargue, G. Guerin, and M. Clerjeau. 1999. Fruit resistance to Colletotrichum acutatum in strawberries. Plant Dis. 83:549-553.

Eastburn, D.M. and W.D. Gubler. 1992. Effects of soil moisture and temperature on the survival of Colletotrichum acutatum. Plant Dis. 76:841-842.

Eastburn, D.M. and W.D. Gubler. 1990. Strawberry anthracnose: Detection and survival of Colletotrichum acutatum in soil. Plant Dis. 74:161-163. 
Forster, H. and J.E. Adaskaveg. 1999. Identification of subpopulations of Colletotrichum acutatum and epidemiology of almond anthracnose in California. Phytopathology 89:1056-1065.

Freeman, S., S. Horowitz, and A. Sharon. 2001. Pathogenic and nonpathogenic lifestyles in Colletotrichum acutatum from strawberry and other plants. Phytopathology 91:986-992.

Freeman, S., D. Minz, I. Kolesnik, O. Barbul, A. Zveibil, M. Maymon, Y. Nitzani, B. Kirshner, D. Rav-David, A. Bilu, A. Dag, S. Shafir, and Y. Elad. 2004. Trichoderma biocontrol of Colletotrichum acutatum and Botrytis cinerea and survival in strawberry. Eur. J. Plant Pathol. 110:361-370.

Freeman, S., Z. Shalev, and J. Katan. 2002. Survival in soil of Colletotrichum acutatum and C. gloeosporioides pathogenic on strawberry. Plant Dis. 86:965-970.

Galletta, G.J., B.J. Smith, and C.L. Gupton. 1993. Strawberry parent clones US 70, US 159, US 292, and US 438 resistant to anthracnose crown rot. HortScience 28:1055-1056.

Goheen, A.C. and J.R. McGrew. 1954. Control of endoparasitic root nematodes in strawberry propagation stocks by hot-water treatments. Plant Dis. Rpt. 38:818-826.

Goheen, A.C., J.R. McGrew, and J.B. Smith. 1956. Tolerance of strawberry plants to hot-water therapy. Plant Dis. Rpt. 49:446-451.

Gubler, W.D. and D.M. Eastburn. 1988. Research progress report: anthracnose in California. Adv. Strawberry Production 7:47-50.

Horowitz, S., S. Freeman, A. Zveibel, and O Yardin. 2006. A defect in nirl, a nirA-like transcription factor, confers morphological abnormalities and loss of pathogenicity in
Colletotrichum acutatum. Mol. Plant Pathol. 7:341-354.

Howard, C.M. and E.E. Albregts. 1973. Cassia obtusifolia, a possible reservoir for inoculum of Colletotrichum fragariae. Phytopathology 63:533-534.

McInnes, T.B., L.L. Black, and J.M. Gatti. 1992. Disease-free plants for management of strawberry anthracnose crown rot. Plant Dis. 76:260-264

Parikka, P. and A. Lemmetty. 2004. Tracing latent infection of Colletotrichum acutatum on strawberry by PCR. Eur. J. Plant Pathol. 110:393-398.

Peres, N.A., L.W. Timmer, J.E. Adaskaveg, and J.C. Correll. 2005. Lifestyles of Colletotrichum acutatum. Plant Dis. 89:784-796.

Sjulin, T.M. 2003. The North American small fruit industry 1903-2003. II. Contributions of public and private research in the past 25 years and a view to the future. HortScience 38:960-967.

Smith, B.J. 1987. Effect of nitrogen, phosphorus and potassium on the severity of strawberry anthracnose crown rot. Phytopathology 77 : 1691 (abstr.).

Smith, B.J. 1998. Anthracnose crown rot, p. 46-48. In: J.L. Maas (ed.). Compendium of strawberry diseases 2nd ed. APS Press, St. Paul, MN.

Smith, B.J. and C.L. Gupton. 1993. Calcium applications before harvest affect the severity of anthracnose fruit rot of greenhouse-grown strawberries. Acta Hort. 348:477-482.

Smith, B.J., C.L. Gupton, G.J. Galletta, J.L. Maas, J.M. Enns, J.R. Ballington, Jr., R.J. Constantin, T.J. DiVittorio, and D. Himelrick. 1998. 'Pelican' strawberry. HortScience 33:1082-1084.

Smith, L.M. and E.V. Goldsmith. 1936. The cyclamen mite, Tarsonemus pallidus, and its control on field strawberries. Hilgardia 10: 53-94.

Sreenivasaprasad, S. and P. Talhinas. 2005. Genotypic and phenotypic diversity in Colletotrichum acutatum, a cosmopolitan pathogen causing anthracnose on a wide range of hosts. Mol. Plant Pathol. 6:361-378.

Strand, L.L. 1994. Integrated pest management for strawberries. Publication 3351. University of California Statewide Integrated Pest Management Project. Regents of the University of California, Division of Agriculture and Natural Resources, Oakland, CA.

Turechek, W.W., N.A. Peres, and N.A. Werner. 2006. Pre- and post-infection activity of pyraclostrobin for control of anthracnose fruit rot of strawberry caused by Colletotrichum acutatum. Plant Dis. 90:862-868.

Wilson, L.L., L.V. Madden, and M.A. Ellis. 1992. Overwinter survival of Colletotrichum acutatum in infected strawberry fruit in Ohio. Plant Dis. 76:948-950.

University of California Statewide Integrated Pest Management Program (UC IPM Online). 2004. Weed photo gallery listed by scientific name. $<$ http://www.ipm.ucdavis.edu/PMG/weeds_ scientific.html $>$.

United States Department of Agriculture (USDA). 2004. Plants database. $<$ http://plants.usda.gov/>.

Yang, X., L.L. Wilson, L.V. Madden, and M.A Ellis. 1990. Rain splash dispersal of Colletotrichum acutatum from infected strawberry fruit. Phytopathology 80:590-595.

Yoshida, S. and T. Tsukiboshi. 2002. Shoot blight and leaf spot of blueberry anthracnose caused by Colletotrichum acutatum. J. Gen. Plant Pathol. 68:246-248. 